Hume, M. and Wilding, P. (2020) Beyond agency and passivity: situating a gendered articulation of urban violence in Brazil and El Salvador. Urban Studies, 57(2), pp. 249266. (doi: $10.1177 / 0042098019829391$ )

There may be differences between this version and the published version. You are advised to consult the publisher's version if you wish to cite from it.

\title{
http://eprints.gla.ac.uk/177362/
}

Deposited on: 9 January 2019

Enlighten - Research publications by members of the University of Glasgow http://eprints.gla.ac.uk 


\section{Beyond Agency and passivity: situating a gendered articulation of urban violence in Brazil and El Salvador}

\section{Introduction}

Latin America demonstrates the highest homicide rate in the world for nonconflict zones and rates of interpersonal violence are extreme, if underreported (Moser and Mcllwaine, 2014). Much of this violence occurs in cities (Muggah, 2012). Urban spaces produce different opportunities and constraints for men and women in terms of their negotiation with everyday violence; yet the wider gendered politics of urban violence and the fact that men and women experience insecurity differently are often overlooked in both research and policy considerations (Datta, 2016). The separate trajectories of the study of intimate and gendered violence from 'mainstream' violent crime and its measurement has resulted in the invisibilisation of women in urban crime data (Walby et al., 2014). Cities per se do not generate violence against women and girls (VAWG) but processes of urbanisation can create heightened risk factors and indeed opportunities, which are deeply gendered (McIlwaine, 2013). So-called 'triggers' for increased VAWG might include poverty, changing gendered norms, particularly around increased participation of women in the labour force, the lack of social support, and the growing complexity of violence that women must endure. These issues are all underpinned by inequalities arising from deeply patriarchal societies (Prieto-Carrón et al., 2007; Menjívar, 2011; Carey and Torres, 2010).. Nonetheless, authorities appear indifferent to their responsibility to investigate and prosecute gendered crimes despite a wave of specialised laws that have been implemented over the last two decades in Latin America (De Campos, 2015; Boesten, 2012; Neumann, 2017). Reasons for this indifference are varied - not least, that the issue is not considered an official priority in contrast to more lethal episodes of urban violence such as gang confrontations (Hume, 2004).

Against this impunity, a paradox emerges where 'success' in domestic violence programmes is overwhelmingly measured within rational choice frames of leave-prosecute, and women are commonly blamed for the violence they must endure (Westmarland and Kelly, 2013; Brickell, 2015). Our research in the urban margins of Rio de Janeiro and San Salvador uncovers the on-going hegemony of normative logics - from both conservative and liberal quarters - that present women with contradictory messages on managing their security. Bolstered by openly misogynistic and violent politics' ${ }^{1}$ conservative notions of 'keeping the peace' and not breaking up the family compel women to accept intimate partner violence (IPV) as 'the simple fact of being a woman' (Hume, 2009b:83). In contrast, liberal 'progressive' messages urge women that their options are to either leave the relationship and/or engage in formal legal proceedings against her partner. However, this assumes that women have somewhere to go, and that the neoliberal state, communities and families can and will provide protection. 
High levels of impunity and the constraining effects of the wider gendered context of urban violence are ignored. We argue here that the gendered politics of urban violence are shaped by locally specific configurations of political and cultural institutions, agents, and social practices. Together, these interact with and impede individual agency, resulting in complex, and often contradictory strategies. Women in our research who endured long-term IPV, without seemingly engaging in formal proactive strategies to end their relationships or engage in legal proceedings against their partners, were often dismissed as either 'provoking' or even 'enjoying' violence. However, conversations with these women revealed a more complex picture that points to agency as a process, not as an end goal. Failing to understand women's multiple, changing and often contradictory positionalities presupposes passivity. Few ask what women can do when confronting sustained violence over time and in multiple spaces (Cavanagh, 2003; Pain, 2014) or indeed how spaces of urban violence actively constrain women's agency (Mcllwaine, 2013).

In response, this paper argues for a situated politics of women's agency in enduring IPV in contexts of extreme urban violence. We contend that interrogating agency as dynamic and lived facilitates an acknowledgement of the multi-scalar entanglements of violence across urban spaces. Drawing on critical urban scholarship and feminist theory involves recognising the complexities in human agency and holds the potential for a radical gendered urban politics to emerge whereby people are neither simplistically victims nor pawns of violent processes, but located within dynamic 'webs of social relations' (Cumbers et al., 2010: 54; McNay, 2010:117). This articulation rejects dominant (liberal) conceptions of 'agency' that refer to an individual's capacity for action, unfettered by structural social and political dynamics (Ahearn, 2001). Instead, we build on and extend longstanding debates across the social sciences that push for an analysis of agents and structures as 'co-determined' (Wendt, 1987), situated (Williams, 2015) and therefore dynamically 'entangled' within wider social relations (Muñoz, 2016). Through an articulation of ways in which women's actions are embedded in a wider urban political economy of violence (Datta, 2016; Auyero and Berti, 2015), we therefore contend that women's engagement and non-engagement with the state can be understood not as evidence of passivity and ambivalence, but as a critical act.

The article is divided into three sections. First, we elaborate our theoretical framework, drawing explicitly on feminist theorising of agency. Second, we outline the methodological approach and data collection methods. The third section explores the ways in which a situated politics of agency allows for women's small acts and quiet politics to emerge. Foregrounding these enhances our understanding of the gendered dynamics of urban violence. 


\section{Shifting the gaze: a situated articulation of women's agency in violent urban spaces}

While there has been much written about women's transformative agency as a strategic goal of feminism, less has been written about the everyday ways in which women experience, survive, challenge and resist IPV in contexts of dynamic and multi-sited violence (Zulver, 2016). This section proposes a situated conceptualisation of women's agency that can account for the multiple forms of violence that shape women's spaces for action. Firstly, we contextualise competing and contradictory notions of agency from both liberal and more progressive positions to show that neither can fully capture women's lived experience of urban violence. Secondly, our articulation of agency interrogates the space between its idealised transformatory goals and women's everyday lived practice in a violent city. Finally, we ask whose agency matters when discussing violence and why, from a feminist perspective, discussion and ascription of agency is necessarily a political act. Situating the multiple ways in which women can and cannot exercise agency problematizes the policy tendency to portray the state, the community and the family, as necessarily safe spaces for women, and allows us to see how these spaces entangle to compromise women's security. Instead, women's agency is analysed within the context in which women are able to act. Informing this analysis is the fact that 'constraints' on agency are not constant, but are 'renegotiated, reworked and politicized in different ways' (Featherstone and Griffin, 2016).

In order to explore the everyday ways in which women survive, challenge and resist IPV in contexts of dynamic and multi-sited violence, a first step is to acknowledge the historically, culturally and spatially contingent nature of agency. Mahmood (2001:206) reminds us of 'feminism's dual character as both an analytical and a politically prescriptive project'. The tensions in this duality play out in our discussions of agency here - between its progressive ideals and the constraining forces present in women's lives, which are compounded in urban settings by higher levels of violence than other places (Muggah, 2012). Much feminist engagement with agency centres on transformative and emancipatory action. Kabeer (2003), for instance, states that: "the transformative potential of agency lies in an improvement in women's ability to question, reinterpret and perhaps change [their] roles and responsibilities." Hegemonic neoliberal institutions, which are deeply gendered, do not seek agency in transformative politics, but locate it in individual (not collective) survival strategies. Within the agency/passivity binary, women exiting a relationship, and ideally prosecuting the perpetrator, are considered proxies for "success" in domestic violence programmes, while legal processes initiated by women are understood as individual justice seeking and not attempts to redress structural inequities (Westmarland and Kelly, 2013). In this liberal sense, women's agency is often conflated with free will - and individual choice - as if 
these decisions to leave and prosecute violent partners were simple and clear cut. Free will, as Wilson (2008) points out, is "central to the philosophical underpinnings of capitalism". Similarly, critiques of the growing hegemony of 'resilience' in policy arenas foreground how the focus on individuals' supposed capacity for action supplants a critical interrogation of the inequalities and injustices present in the social structure (MacKinnon and Derickson, 2013:258). Agency in this liberal sense is therefore forcibly and politically separated from wider structural forces. The analytical challenge is to contest the dominant script of a freely choosing individual, recognising the limiting context, while "retain[ing] some sense of human agency, the capacity of social beings to interpret and morally evaluate their situation and to formulate projects and try to enact them" (Ortner, 1995:185).

Neither liberal nor transformatory perspectives can sufficiently capture the complexity and ambiguity of women's agency in addressing experiences of violence in diverse spaces. This demands more grounded analytical work in actually existing urban lived environments to avoid disconnecting women's capacity for action from 'cultural and economic forces, identity formations and social structures' (McNay, 2004:177). This approach resonates firmly with Williams' (2015) concern to move beyond a reductive view of agency as simply resistance to power. Taken together these push us politically and analytically, demanding recognition of the everyday challenges of women who live on the margins of cities in the Global South where life is governed by dynamic forms of structural, social and political violence. Socio-environmental forces entwine with human capacity for action, providing both impetus and obstacle. Situating our understanding of agency in this dynamic way challenges prevailing logics within violence debates that appear to divorce women's experiences from the local violent contexts in which they reside. Accordingly, Datta encourages us to think about women's agency as the effort to lead an 'ordinary life within a framework of violence' (2016:329 citing Das, 2004).

As feminist researchers, we share a political commitment to a transformative ideal of agency, but problematize what this means in practice. The lived space between ideal and actually existing agency is at the heart of our argument here. In this sense we agree with Bilge's (2010) critique of a 'content-dependent understanding of agency' in which the 'content' of women's behaviours is judged against predominantly (gendered) liberal values, effectively discounting those actions that do not align. ${ }^{2}$ Our engagement with women's actions in contesting IPV therefore refuses the temptation of reducing these to whether they 'fit' within a wider liberal agenda or transformative politics or not.

The challenge that arises is to explicitly reclaim the concept of local lived agency from its idealised and aspatial liberal articulation. In this sense, we respond to Cumbers et al.'s (2010) call for a 'deeper' sense of agency to allow a more politically empowered understanding of women's responses to IPV in contexts of 
extreme urban violence. Agency in violence is often confined to the violent aggressor and is therefore implicitly masculinised, ignoring both its relational dynamics (Kelly, 2000) and the fact that IPV is not a series of individual incidents, but an on-going process (Wilcox 2006). Associating agency primarily with the use of violence has particularly gendered and spatial implications, both in refusing the agency of those who endure violence and in ascribing intimate relations with a privacy conflated with idealised notions of the physical space of the home. This perceived gendered spatiality effectively insulates IPV and its perpetrators from public scrutiny while women's status as passive victims remains both 'deep and persistent' (Pain, 2014:129). In contrast to such liberal scripts, women's testimonies highlight the multiple ways they respond, to emphasise ways that fall outside the reductive leave/prosecute paradigm.

Even when women do take the socially sanctioned steps of leaving or reporting violence, what precedes these steps is complex, spatially variegated and all too often messy. Ending violent relationships is rarely straightforward and often incomplete (Cavanagh, 2003; Pain, 2014), yet women's preceding and concurrent actions are not necessarily recognised by state and non-state agencies as constituting "agency". Instead, women often refuse the violent status quo in small ways as well as overtly transformative ones. As argued, it is therefore important not to judge the repertoire of women's actions in 'purely instrumental terms' since this misses ways in which the process of struggle itself can build capacity and have cumulative effects (Elson and Pearson, 1981; see also Pain, 2014). ${ }^{3}$ Katz (2004:247) calls for attention to the 'small acts' that may not overtly challenge hegemonic power, but can constitute an "attempt to recalibrate power relations" through a continuum of actions. These might range from deflecting immediate threat to challenging men's coercive behaviours in overt and subtle ways. In distinguishing between the variable practices of agency, which are spatially and socially contingent, Katz highlights their uneven and contradictory outcomes whether working within, or challenging, existing power relations. ${ }^{4}$ Acknowledging the salience of these small acts opens up the radical potential of women's different actions. Taken as a whole, it becomes clear that women's actions might not transform their relationships with men in line with liberal prescriptions of what this transformation should look like, but also their actions may allow for survival, or even recovering dignity, while leaving uncontested the status quo in the wider gendered politics of power.

Our relational understanding of agency therefore recognises the 'everyday' stresses that women face in order to cope with their violent reality (Bilge, 2010). Here the concept of 'quiet politics' is useful to both draw attention to those actions that go unnoticed or are 'inaudible' to liberal audiences (Hankins, 2017). This allows women's 'small acts' to be seen as political even if they would not 'count' in either liberal or transformative senses (Katz, 2004:244). Rather than dismissing women as passive, the concept of quiet politics foregrounds the 
explicit actions of women, reflected in their 'political will' and 'commitment' to engage (Askins, 2015:476). This shifts our gaze to 'the ways in which everyday decision making by individuals and communities can gradually, episodically change dominant hegemonic norms and understandings' (Hankins, 2017:503). Thus, exploring the range of less visible, less knowable, and indeed less readily 'countable' actions and emotions in relationships of violence challenges any assumed passivity, and makes way for understanding some behaviours as transgressive in their refusal to fully conform to their oppression (see Engle Merry, 2016).

The critical interrogation of women's agency we propose here foregrounds the inequalities and injustices present across and within different spaces, which sustain and support - and crucially fail - women. Key to this approach is to challenge the emphasis placed on women's individual responsibility for controlling men's violence, as the singular determining force in ending violent relations, a value which has seeped into policy formulation across the globe (Thapar-Björkert and Morgan, 2010; Dobash and Dobash, 1979). In practical terms, this means giving due weight to the varied reasons for women not reporting violence, and shifting our gaze to the potential problems with the options available. In doing so, we challenge the reduction of individual women to the role of 'victim-survivor' of one particular relationship of violence, and IPV as a crude dyadic encounter between two individuals, instead understanding violence as an interactive process - within social structural and diverse local and national social and cultural practices - where certain types of gendered violent behaviour are both 'legally and socially excused' (Carey and Torres, 2010). By acknowledging that women's responses are multiple and often ambiguous, our critical gaze is shifted from individual women to the lived urban spaces in which they reside. Thus we embed our consideration of agency in more complex, dynamic and spatially situated gendered accounts of violence.

\section{Methodology}

Our research has been developed in contexts in which urban violence and security concerns are evolving and dynamic. This dynamism necessitates an iterative, adaptive and reflexive research design, which we underpin with principles of feminist research; i.e. research that is politically motivated in that it seeks to challenge social inequality, recognises that data collection is never value free, and engages centrally with issues of gendered power and reflexivity (Nast, 1994; England, 2005).

The data we draw on here came out of two distinct projects that shared a common research design, methods, and question schedule. We made a clear methodological choice to work collaboratively with local organisations. In El Salvador, Author 1 carried out her research in collaboration with a Programme to Prevent Gender Violence (PPVG) with which she has been working since 2007, 
a national coalition of actors that brings together feminist organisations, schools, governmental bodies and civil society organisations to develop key initiatives to prevent gender violence. In Brazil, Author 2 worked with a range of local NGOs and community groups that do not explicitly focus on gender violence, but deal with it in their everyday interactions and activities. Our participants, therefore, are women who have direct or indirect experience of gender violence. Our data collection between 2014 and 2016 combined a mixture of qualitative methods (14 focus groups, 4 workshops, and 30 semi-structured interviews across both countries) with secondary quantitative and qualitative data analysis. This mixed qualitative approach allows for multiple entry points to the problem of violence and produced situated understandings of women's strategies when facing IPV.

Although different in size, political trajectories, patterns of violence, and global links, the cities of San Salvador and Rio de Janeiro share characteristics common to many in Latin America. Both demonstrate high levels of violence, which are spatially concentrated at the urban margins, and demonstrate increasingly high rates of femicide (UNODC 2013:128). Brazil and El Salvador are characterised by extreme inequality (UNDP, 2013), which has been exacerbated by neoliberal imperatives that have shaped the development agenda in both countries over the last thirty years. It is within this context of extreme violence and political and economic marginalisation that this research is located. Our goal was not to compare the different cases but, following Auyero (2011:432), to see how 'lessons learned about one urban reality can act as interrogating arrows' to point us 'toward new kinds of inquiry' and, in this case, the critical interrogation of how intersecting violences shape women's capacity for action. Datta (2012:3) argues that the urban poor occupy a 'space between a rule of law and its enforcement'. Accordingly, our political ethnographic approach, which pays attention to both the shifting formal political arena and the 'quiet politics' of everyday life, seeks to interrogate the dynamic 'informal institutions, unwritten rules, and gendered and raced norms, which are in tension with formal institutions and laws' (Behi, 2016:50).

The research participants fell into two broad groups: local residents and service providers/activists involved in organisations working in these areas. We used our experiences from each case to develop and refine the research questions and engage with ethical issues in an iterative way. Focus group discussions explored participants' views on, and knowledge of, women's strategies, legislative changes, and changes in policing and security, and were supplemented with individual interviews to allow for a deeper exploration of more personal stories. The conversations were transcribed and thematically analysed in an iterative process that involved both researchers cross-referencing themes and analytical categories across the data sets. This grounded methodology allows for the themes to evolve, while acknowledging how the specific research goals directed the overall questioning and the selection of illustrative examples. Through these 
techniques, we engaged in productive conversations to develop the research, which specifically explored women's responses to violence and the constantly shifting context of security.

We do not attempt to represent all women's experiences in these areas, nor generalise from narratives that inevitably pertain to their own specific contexts and have their own particularities; rather dissent, disagreement and divergent views all provided fertile ground for discussion in focus groups. Examples have been chosen for sharing similarities and patterns with other narratives and for resonating with our conversations with activists, researchers and service providers over multiple periods of fieldwork. The data therefore provide indepth insights and narratives of women's experiences and options to open up a situated discussion of their 'spaces for action'.

\section{The context of fear and risk: institutions, actors and violence}

The specifics of different cities, and spaces within them, result in different vulnerabilities for different women at different times but, as McIlwaine (2013:) affirms, the relationship between cities and VAWG is not straightforward. Cities can provide spaces of both increased risk and vulnerability, as well as potential support (Moser and Mcllwaine 2014:338). Nevertheless, in urban contexts where multiple violences co-exist, even recognising IPV cannot be taken for granted. Our interrogation of women's life histories reveals that violence has been a 'normal' part of their lived experience from infancy. The normalisation of VAWG coupled with the perception that certain forms of violence in the wider urban context are more 'serious' undermine women's agency. This section engages our theoretical framing outlined above to explore both the situated politics of agency and the ways in which women actively recognise and negotiate the constraints imposed upon them in contexts of extreme urban violence. We highlight three specific constraints identified by our research participants: the inefficiency and indifference of state institutions; the local landscape of violence and the localised rules that violent actors impose; and prevalent social acceptance of violence against women. We then offer examples of how women negotiate these constraints. Foregrounding this complex and shifting landscape challenges simplistic assumptions of women's passivity and forces a shift towards recognising women's non-engagement with the state as a critical act. Women's different actions explored here may go unheard or uncounted in formal spaces, but they challenge any dismissal of women as merely passive victims of IPV.

Despite progressive legislation on VAWG being passed in both countries, women's experiences confirm that the legal system often fails them, which is indicative of an "implementation gap" between "the letter and the application of the law" (Macaulay 2002; see also Datta, 2012). ${ }^{5}$ Patchy progress in the implementation of progressive laws feeds into long-standing ambivalence among 
feminist scholars and activists about the benefits of legal reform, with the legal arena representing both a space of domination and of social transformation for women (Cornwall, 2013; Brickell, 2015). The fact that this ambivalence is given no place when determining policy prescriptions for what women should do when facing violence alerts us to the ways in which certain women's voices are muted or remain 'inaudible' to policy formulation (Hankins, 2017). Interview narratives recognise the ways in which this 'gap' is directly mediated and controlled in formal and informal ways via a series of gatekeepers, which include criminal justice professionals and a host of other state and non-state actors, from key political figures to the security guards in government offices, as well as nonstate violent actors (see Neumann, 2017 on Nicaragua). In the words of a Salvadoran participant: 'even the security guards want to mistreat us [just] because we want to access state services, but now we no longer remain quiet'. Women must therefore find ways of negotiating the disconnect between national legal frameworks that promise protection and localised service provision that often discriminates across gendered as well as ethnic, racial and class lines (see Datta 2012 on Delhi). The ways they do this can be both subtle and more radical.

Decades of research from different contexts have shown that the immediate period around leaving the relationship is the most dangerous for women, something routinely ignored by state institutions (Fleury et al., 2000). Thus, even when women choose the socially sanctioned route of engaging the authorities in the issue, a lack of a timely response puts women at risk of retaliation from their violent partners. Many participants speak of having been 'punished' for daring to speak out or, in one case, suffering days of intense abuse following the filing of a compliant, before the police finally arrested the perpetrator. Even when cases go to court, women argue that the law is not applied evenly or fairly. One public prosecutor lamented the 'purely sexist' rulings meted out by judges after the promulgation of the specialist law in El Salvador. Women in our research repeatedly testified to the fact that multiple institutions have held them responsible for the violence they experienced. In both contexts, participants expressed awareness that institutional responses are uneven and an enduring institutionalised machismo means that interactions with the state are frequently marked by discrimination against women on the basis of race, class and gender. Research participants expressed clear awareness of intertwined processes of 'revictimisation' and victim blaming. In Rio, women have been advised by authorities to "hit him or leave, we're not helping", or to "go to a relative's house, don't waste time filing a complaint", while in El Salvador women are repeatedly asked 'what did you do to provoke him?' or have been admonished for leaving their children without their father'. As a result, they often only feel like they are 'heard' when it is too late and there is no formal route available for justice. Thus, contrary to policy assumptions, bringing private abuse into the public domain does not automatically result in feelings of strength and liberation, and may 
come with significant risk. Whether this is through a lack of resources and/or political will, it can be understood as a clear case of the state facilitating violence (Boesten, 2012).

This facilitation can be seen in the uneven treatment women receive in state services across different spaces. In Brazil, black women from low-income neighbourhoods claimed that they weren't "Marias" (in reference to the Maria da Penha law), suggesting that they are not the 'right kind' of woman (in terms of race and class) to receive support or to be believed. Another respondent from Rio pointed out that violence is embedded in its structures and forms of interaction, in the way that the state itself uses violence to resolve problems, responding with violence rather than arresting, or treating white and black people differently. In El Salvador, respondents focused explicitly on power and class, recognising the need for personal contacts to facilitate access to state agencies. Even state officials agreed that it was important to 'recommend' women to state institutions in order for them to be 'treated well'. Additionally, the urban topographies of certain informal areas make entry and exit difficult both for residents and police forces. Our findings have echoes in other conflict and post-conflict contexts such as Northern Ireland, where local violent conditions have curtailed the police from entering certain areas after dark or without significant resources (McWilliams and Ní Aoláin, 2013). So, although institutions may have the legal powers to protect women from violence, women still carry the burden of responsibility for managing their own safety in their local lived environments, especially if these are homes to other violent actors. While our findings expose the myth of the liberal state as a guaranteed place of safety for marginalised groups, they also illustrate that women articulate clearly the multiple inequalities embedded in accessing justice. The fact that women can and do recognise the risks in pursuing formal channels inevitably shapes the actions they take to challenge violence. We should therefore not be surprised that women perceive criminal justice professionals as complicit with other men, when experiences and narratives such as these circulate, fuelling suspicions of the authorities. The act of recognition, and responding accordingly, is evidence that women's strategies are neither passive nor dislocated from wider institutional dynamics.

The spatial dynamics of wider urban violence further compound these institutional forms of machismo, with women risking retaliation from other violent actors in their neighbourhood for 'daring' to speak to the authorities. Women and men in our research communities attested to feelings of fear of being killed by gangs if caught talking to the police, or being accused of gang activity if caught talking to gang members. Crucially, the local practices of security shift regularly, either through the introduction of new security policies, such as Rio's so-called 'pacification' policies (Cano, 2012), changes in armed criminal groups, or the ways in which the various actors and initiatives interact 
with one another, producing highly dynamic and localised configurations of armed actors and sources of insecurity. So, in efforts to break the connections between gangs and police, for example, policies may loosen the hold of gang rules in some areas for some time, but the way this is experienced on the ground is dependent on the constant realignment of local power relations and micro politics of the neighbourhood, as well as an individual's own personal relationships within the community. What remains constant throughout, however, is persistent uncertainty and risk, with clearly gendered contours.

Pain (2014:127) has highlighted how the specific gendered location of intimate partner violence enforces 'spatial entrapment' of women. Research participants indicate that violent partners limit their movements outside the home in multiple ways. In these contexts of high urban violence, entrapment is further variegated with the spatially embedded and dynamic nature of overlapping violences having a particularly controlling effect. Gangs in both contexts, for example, can explicitly prohibit residents of rival gang territories entering their space. This has huge implications for social networks and also for accessing state services such as local health clinics, or NGOs. Equally, in both contexts police are suspected of colluding with local gangs and criminal groups. Participants identified the enmeshing of different armed actors in how off-duty police and security services have formed into militias in Brazil and 'share the spoils' of crime in El Salvador. As perpetrators of violence against women shift their allegiance from one armed group to another, threats can increase or mutate for women seeking justice or a way out.

The restrictions women face from armed actors intertwine with sanction from the wider community based on what is deemed appropriate behaviour. The dual standards that dominate sexual norms are not lost on women. While a man having multiple partners is accepted, demarking him as a ladies man or a stud, in Brazil a woman is classed as "a cheater (safada)". Participants of focus groups in both contexts frequently referred to the damaging effects of gossip, and that even family members may report back to abusive husbands while, despite gang laws ostensibly prohibiting hitting women, continuing to perpetuate the idea that "he is your husband, he can hit you". In response, many argue that it is best to remain quiet and only speak to trusted friends and neighbours. So rather than silence as evidence of passivity, it becomes an important - albeit not readily 'audible' survival strategy in contexts of extreme urban violence (Hume, 2009a).

Community 'sanction', therefore, can be in the form of social control - gossip, insults etc. - but also women speak about the constant threat of sexual violence and harassment, at the hands of both gangs who pick out young women to be their "girlfriends", and the police who feel free to harass young women from poor neighbourhoods, as if they have "no value" - including when they are posted within school grounds. The gendered dynamics of school desertion, internal displacement in these communities, and changing gendered routines are 
under studied and poorly understood, meanwhile the control of women's lives extends from public to private spaces. The very threat of sexualised violence is recognised as a clear way of controlling women's behaviour, particularly by criminal gangs, preventing women going out alone and "controlling us in advance". Such threats reinforce the need to 'control' women's use of public space and many participants suggested they nourish social norms that insist women 'need' men for protection (see Young, 2003).

Put together, these factors do not just sustain a local climate of impunity for VAWG, but support an analysis of women's agency within a wider context of patriarchal violence - in diverse spatial settings within the city. Our research participants stress the ways in which lack of trust in state institutions further reinforces structures of impunity and women's isolation is exacerbated by locally regulated community codes of silence that further undermine women's formal justice seeking behaviour. Both state and non-state forces deny women protection when they need it most, in both formal and informal ways. Highlighting women's experiences of interacting with an array of formal and informal institutional actors, different manifestations of urban violence emerge as gendered and entangled. In other conflict contexts, women activists testify to living in 'armed patriarchy' where wider politics of conflict provide heightened opportunities for coercive behaviours among a range of men (McWilliams and Ní Aoláin, 2013). The gendered effects of everyday control and the increasingly blurred lines between legal and illegal armed actors not only limit women's mobility and livelihood opportunities, but also decisively inform their available spaces for action.

Even in these stories of revictimisation, harassment and humiliation, research participants provided evidence of women's tenacity, their willingness to challenge the status quo - there would be no stories if women were merely 'passive'. It is women's very recognition of the gendered entanglement of different forms of violence and oppression that underpins their critical refusal of the state as a place of refuge. Consequently, women prioritised the need to forge safe spaces - formal and informal - in these violent urban spaces albeit with the dangers this implies. What might easily be dismissed as a small act, particularly when set against the leave-prosecute paradigm, is women seeking out spaces where they can talk about these issues, whether that is seeking help from family members, sympathetic neighbours, from NGOs in the community, health centres, or the church. ${ }^{6}$ A community leader in El Salvador spoke about the importance of helping women in spaces in which she is 'allowed to move', referring to rules of movement imposed by gangs across her local area limiting who can go where. For many of our interviewees, spaces where they can 'open up' and feel welcomed, particularly for LGBT women, are sorely lacking. Although some organisations try to fill this gap, many women are not aware these are places where they can seek help - and many communities do not have an organisation 
that deals with IPV. Research participants who participate in such spaces argued that it was their 'duty' to share their knowledge and accompany other women. While this may be a small, quiet act, it evidences that women refuse to remain passive.

In part perhaps due to this scarcity, women tend to seek out more informal - and perhaps less obviously direct - sources of support. A Brazilian health worker suggests that women prefer to avoid the police or formal institutions because 'they do not want to be a statistic - they want a solution'. 'Solutions' often concentrate on the immediate management of threat - examples include placating the man, hiding in neighbours' houses, or as a last resort reporting to the authorities even if it only for him to 'calm down'. These are common strategies, but what adds risk in these urban environments is that even leaving the supposedly 'safe' space of the home to use a public telephone or seek shelter, is potentially exposing themselves to additional danger, while the high circulation of guns in these cities intensifies risk. Despite this, women's 'small acts' in these conexts are often precisely those dismissed by authorities as evidence of women's passivity and culpability. For example, state officials repeatedly express frustration when women take the step of reporting violence but do not follow up with prosecution. This is an exemplar of victim blaming, when women do not meet the normative expectations of being a 'good client' (Dunn 2005 in Brickell 2017:1365). As shown above, women's 'oscillating use/rejection of the law' may result from its inadequacy in reality (Brickell: ibid). Equally important are the multiple reasons women might have for remaining in a relationship. However precarious, these may range from love, a sense of economic security and, as suggested previously, the need for male 'protection' against wider urban violence. Women also mention the 'social value' of being in a relationship in a patriarchal society (see also Wilcox 2006).

The deeper territorialisation of crime and violence in urban areas affects how and where women can access support. In El Salvador, women who participate in the PPVG organise around 'Citizen Windows' to support friends and neighbours and advocate for women's rights at a local level. These are supported by local NGOs. Many members are survivors of violence and while some have left violent partners, others remain in the relationship but try to negotiate their safety in various ways. As above, the practical difficulty of moving from one neighbourhood to another is exacerbated by territorial conflicts between different gangs. Data from San Salvador show that this undermines (but does not erode) co-operation between women from different communities. Women negotiate danger from multiple sources in their local areas to forge alliances with other women. Zulver (2016) has termed this 'high risk' feminism. Strategies include meeting in 'neutral' areas, 'negotiating'7 with gang members and seeking the shelter of religious or cultural institutions. Interviewees testified to the importance of both practical and strategic 'hooks' and 'shields' to facilitate 
women's participation in such spaces. ${ }^{8}$ Practical 'hooks' might include offering women a material benefit - e.g. a bag of rice or engaging in crafts - but these also work as 'shields' for women returning to controlling partners with a 'tangible' benefit. They also 'shield' against local violent actors who might be less threatened by what looks like a group of women chatting and engaging in crafts, rather than discussing violence. ${ }^{9}$ This varied across spaces both within cities and across the two cases. For example, in one area women suggested gangs were not bothered whereas in another, women testified to having to take extra care and having to mitigate against 'spies' who then report everything to gang-members. This means that confidentiality and trust among groups are crucial, especially when some of the women participating themselves have close familial ties to armed groups. In contexts of scarce resources and without external support, accessing additional resources can be difficult and in finding ways around this, women really challenge any stereotype of passivity. Examples include pooling scant resources, single women looking out for those in situations of violence or building on existing skills to offer training.

Considering that many of the research particiapants have had limited access to formal education, they spoke at length about the importance of learning as a valuable communal resource and also something personal just for them: "what I have in my head can't be taken away by anyone. If I go somewhere else, I take it with me and that is really important to me" (interview El Salvador). The learning itself became an important process in itself and not just a pathway to engaging in formal action. For those women who had taken decisive legal action, having access to information and the capacity to recognise abuse proved key to taking steps to challenge it. Here we can appreciate how for some women, over time these hooks and shields can become more strategic, leading in increased freedom from control, which can potentially lead to more transformative actions. Several woman spoke about using 'knowledge' about their rights or the existence of specialised laws to challenge partners, especially if they have 'proof' of their rights, which might include educational leaflets or posters. Using the law as a deterrent may not be as easily measurable as conviction rates; however, it does show that women can and do make strategic use of its existence as a shield. By listening to the 'inaudible' political voices of women at the urban margins, it is evident that both the violence itself and the actions that challenge it take place over time and are rarely linear. This reinforces our conceptualisation of agency not as discrete 'small acts', but as a process. While these processes may not have a readily identifiable 'instrumental' outcome, and indeed may "overlap, reverse and repeat" (Pain 2014:135), they can also be cumulative, eventually resulting in more visible and decisive strategies.

Citizen windows in El Salvador provide visible spaces that volunteers shape to advocate to prevent gender violence. These range from informal activities for women to come together to chat, to more radical actions that directly confront 
violence. Data show the very careful and creative ways in which members continually analyse and mitigate risk in their everyday activities. Their local and specialist knowledge has shaped, for example, how they best support women to seek help - in both formal and informal ways. In one local authority office they have a regular stall to offer advice to women, wheras in other areas, this is more informal. Citizen windows have engaged in processes of learning about rights and reproducing this learning across their communities. They make their own creative educational materials, often with little or no resources. In 2014, members led research processes in which they also monitored local state institutions and interviewed service users. The research identified and recorded multiple violences across different local spaces - schools, communities and, in some cases, universities. Using their local knowledge to generate evidence, these women leaders are better able to hold institutions to account and advocate for change. Local activist processes may be facilitated by national and international NGOs and while these only involve a minority of women directly, the PPVG also works in schools across El Salvador to build capacity to prevent violence among younger generations. Participants emphasised the importance of scattering these 'seeds' of knowledge far and wide across communities and generations. Womens' reflections on their participation in these spaces emphasises the importance of process rather than outcome - they emphasise that capacity and confidence are built over time. So while their agency, both collective and individual, might not 'fit' the liberal definition, the multiple and often quiet effects of small acts opens up a potential a more radical politics.

This section has argued that the very exercise of looking for women's agency in formalised strategies is both limiting and misleading We have discussed here the ways in which the urban environment of violence and inadequate institutional support systems impede women from finding safe spaces to talk, but we have also shown how these spaces are vital resources to women. Rather than passive, our research participants speak about the creative and dynamic ways in which they struggle to live an 'ordinary life'. Their attempts to produce and articulate safe spaces, and start conversations that recognise and challenge the normalisation of violence, call our attention to the ways in which 'small acts' form part of larger repertoires of action.

\section{Conclusions}

This article makes a key contribution to the gendering of debates on chronic urban violence by proposing a relational and situated analysis of women's agency. Our conceptualisation of agency challenges liberal paradigms that dominate thinking on responses to violence in public and private lives. The paper holds wider resonance for discussions of agency and resistance that miss many of the 'small acts' that are erased from everyday lived experiences of violence on 
urban margins (Katz, 2004). We speak directly to recent debates about diverse and lived urban experiences (Datta, 2016; Muñoz, 2016; Williams, 2015), while at the same time rejecting narratives that hold women responsible for their security in intimate and wider social relations.

By focusing on women's agency as grounded and complex, we do not suggest that the more commonly recognised and socially sanctioned 'transformative' strategies such as leaving or reporting abuse are not important. Attempts to address IPV have often focused around the law, both to act as a symbolic yardstick to frame acts of VAWG as crimes, as well as to provide a framework for judicial processes and redress. Consequently, policy responses in many contexts have been punitive in discourse but marked by impunity in practice (Boesten, 2012). Through foregrounding the connections between different forms of violence, we have shown that the existence of a legal framework does not imply a functioning rule of law - even progressive legislation may be applied unevenly and state programmes targeting violence are often insufficiently resourced. Taking legal action involves both risks and costs, and leaving violent relationships can intensify violence for women. In foregrounding obstacles women face, we intend this analysis to be used as the basis for challenging weak state capacity, systemic gendered subordination, chronic violence and an exclusionary economy.

The situated conceptualisation we therefore advocate for moves beyond the structure / agency 'problem' to view women's multiple strategies as evidence of women's overt and covert critiques of the world around them - in other words a decision not to engage with a particular agency can be a quietly critical act and not merely evidence of passivity. This is not to romanticise women's agency in resisting and coping with violence, but to see these very much as both symptoms and outcomes of on-going processes of (gendered) marginalisation. By understanding women's responses - even when these appear to be 'passive' or contradictory - as a response to the shortcomings of the legal process and the state itself, we challenge assumptions that collapse women's complex strategies to develop non-violent relations into leaving/reporting. Rather than the individual as dislocated from wider structural concerns, we thereby use agency to shift our gaze to problems with the gendered system.

Finally, by opening our analysis to the wider space in which women's agency takes place, this article challenges the static bounding of public and private security that dominates urban violence research. We have argued that it is imperative to foreground the violent landscape of agency - what it means to act within a violent world. In the two contexts of research, the strategies available to women are significantly limited by the chronic violence that surrounds them. 


\section{Bibliography}

Ahearn L M (2001) Language and Agency. Annual Review of Anthropology 30:109-37.

Askins, K. (2015) Being together: everyday geographies and the quiet politics of belonging. ACME: An International E-Journal for Critical Geographies, 14(2), pp. 461-469.

Auyero J (2011) Researching The Urban Margins: What Can the United States Learn from Latin America and Vice Versa. City and Community 10(4):431-436

Auyero J and Berti M (2015) In Harm's Way. Oxford: Princeton University Press.

Behi N (2016) Gendered discipline, gendered space: an ethnographic approach to gendered violence in India. Space and Polity 21(1):43-58.

Bilge S (2010) Beyond Subordination vs. Resistance: An Intersectional Approach to the Agency of Veiled Muslim Women. Journal of Intercultural Studies 31(1):928.

Boesten J (2012) The State and Violence against Women in Peru: Intersecting Inequalities and Patriarchal Rule. Social Politics 19(3):361-382.

Brickell, K (2015) Towards Intimate Geographies of Peace? Local Reconciliation of Domestic Violence in Cambodia Transactions of the Institute of British Geographers. 40(3): 321-333

Brickell K (2017) Clouding the Judgment of Domestic Violence Law: Victim Blaming by Institutional Stakeholders in Cambodia. Journal of Interpersonal Violence 32(9):1-21.

Cano I (2012) 'Os Donos do Morro': uma avaliação exploratória do impato das Unidades de Polícia Pacificadora (UPPS) no Rio de Janeiro. Rio de Janeiro: Fórum Brasileiro de Segurança Pública

Careaga-Pérez G (2016) Moral Panic and Gender Ideology in Latin America. Religion and Gender 6(2):251-255

Carey D Jr and Torres G (2010) Precursors to Femicide: Guatemalan Women in a Vortex of Violence. Latin American Research Review 45(3):142-65.

Cavanagh K (2003) Understanding Women's Responses to Domestic Violence. Qualitative Social Work 2(3):229-249.

Cornwall A (2013) Introductory overview - buzzwords and fuzzwords: deconstructing development discourse. In Cornwall A and Eade D (eds) Deconstructing Development Discourse Buzzwords and Fuzzwords. Rugby, UK: Practical Action Publishing in association with Oxfam GB, pp.1-18.

Cumbers A, Helms G and Swanson K (2010) Class, agency and resistance in the old industrial city. Antipode: A Radical Journal of Geography, 42(1):46-73.

Datta A (2012) The Illegal City: Space, Law and Gender in a Delhi Squatter Settlement. Farnham: Ashgate.

Datta A (2016) The intimate city: violence, gender and ordinary life in Delhi 
slums. Urban Geography 37(3):323-342.

De Campos CH (2015) Desafios na implementação da Lei Maria da Penha. Revista Direito GV 11(2):391-406.

Dobash R E and Dobash R (1979) Violence Against Wives. New York: Free Press.

Elson, Diane and Ruth Pearson. "'Nimble Fingers Make Cheap Workers': An

Analysis of Women's Employment in Third World Export Manufacturing."

Feminist Review 7 (1981): 87-107.

England K (2005) Getting Personal: Reflexivity, Positionality, and Feminist Research. The Professional Geographer 46(1):241-256.

FBSP (Fórum Brasileiro de Segurança Pública) (2017) Visível e invisível: A Victimização de Mulheres no Brasil. São Paulo: FBSP.

Featherstone D and Griffin P (2016) Spatial relations, histories from below and the makings of agency: Reflections on The Making of the English Working Class at 50. Progress in Human Geography, 40(3):375-393.

Fleury R, Sullivan C and Bybee D (2000) When ending the relationship does not end the violence: Women's experiences of violence by former partners. Violence Against Women, 6:1363-1383.

Friedman E J (2009) Re(gion)alizing Women's Human Rights in Latin America. Politics and Gender 5(3):349-375.

Garmany J (2010) Religion and governmentality: understanding governance in urban Brazil. Geoforum 41(6):908-18.

Hankins, K (2017) Creative democracy and the quiet politics of the everyday Urban Geography 38(4): 502-506

Hume M (2004) 'It's as if you don't know, because you don't do anything about it': gender and violence in El Salvador. Environment and Urbanization 16(2):6372.

Hume M (2009a) The Politics of Violence: Gender, Conflict and Community. London: John Wiley

Hume M (2009b) Researching the gendered silences of violence in El Salvador. IDS Bulletin 40(3):78-85.

Hume M and Kane L (2016) 'Ahora hasta nos dicen que somos malcriadas porque no nos quedamos calladas': A study of the programme to prevent gender violence in El Salvador and Guatemala. Oxfam Research Report San Salvador, Guatemala City and Boston: Oxfam.

Kabeer N (2003) Mainstreaming Gender Equality in Poverty Eradication and the Millennium Development Goals: Handbook for Policy Makers. London: Commonwealth Secretariat.

Katz C (2004) Growing Up Global: Economic Restructuring and Children's Everyday Lives. Minneapolis: University of Minnesota Press.

Kelly L (1996) When Does the Speaking Profit Us?: Reflections on the Challenges of Developing Feminist Perspectives on Abuse and Violence by Women. In Hester 
M, Kelly L and Radford J (eds) Women, Violence and Male Power: Feminist Research, Activism and Practice. Buckingham: Open University Press.

Kelly L (2000) Wars Against Women: Metaphor or Reality? Gendered Violence and the Militarised State. In Jacobs S, Jacobson R and Marchbank J (eds) States of Conflict: Gender, violence and resistance. London: Zed Books, pp.45-65.

Lorentzen, LA and Mira R (2005) El milagro está en casa: Gender and private/public empowerment in a migrant pentecostal church. Latin American Perspectives 32(1):57-71.

Macaulay F (2002) Taking the law into their own hands: Women, legal reform and legal literacy in Latin America. In Molyneux M and Craske N (eds) Gender and the Politics of Rights and Democracy in Latin America. Basingstoke: Palgrave Macmillan, pp.79-101.

MacKinnon D and Driscoll Derickson K (2013) From resilience to resourcefulness: A critique of resilience policy and activism. Progress in Human Geography 37(2):253-270.

Mahmood S (2001) Feminist theory, embodiment, and the docile agent: some reflections on the Egyptian Islamic revival Cultural Anthropology 16 (2): 202-36

Mcllwaine C (2003) Urbanization and gender-based violence: exploring the paradoxes in the global South. Environment \& Urbanization Vol25(1):1-15.

McNay L (2004) Agency and experience: gender as a lived relation. In Adkins L and Skeggs B (eds) Feminism after Bourdieu. Oxford: Blackwell, pp.175-190.

McNay L (2010) Feminism and Post-Identity Politics: The Problem of Agency. Constellations, 17(4):512-525

McWilliams M and Ni Aolain F (2013) "There is a War Going on You Know": Addressing the Complexity of Violence Against Women in Conflicted and Post Conflict Societies. Transitional Justice Review 1(2): 4-44.

Menjívar C (2011) Enduring Violence: Ladina Women's Lives in Guatemala. Berkeley: University of California Press.

Molyneux, M; (1998) Analysing Women's Movements Development and Change 29 (2) pp. 219-245

Moser CON and McIlwaine C (2014) Editorial: New frontiers in twenty-first century urban conflict and violence, Environment and Urbanization, 26(2):331344.

Muggah R (2012) Researching the urban dilemma: urbanisation, poverty and violence. Ottawa: International Development Research Centre

Muñoz L (2016) Agency, Choice and Restrictions in Producing Latina/o Street Vending Landscapes in Los Angeles Area 48(3):339-345.

Nast H (1994) Women in the Field: Critical Feminist Methodologies and Theoretical Perspectives. Professional Geographer 46(1):54-66.

Neumann, P (2017) When Laws Are Not Enough: Violence against Women and Bureaucratic Practice in Nicaragua Social Forces 95(3):1105-1125.

Ortner S B (1995) Resistance and the Problem of Ethnographic Refusal. 
Comparative Studies in Society and History 37(1):173-93.

Pain R (2014) Everyday terrorism: connecting domestic violence and global terrorism. Progress in Human Geography 38(4):531-550.

Prieto-Carrón, M, Thomson M and Macdonald M (2007) No More Killings!

Women Respond to Feminicides in Central America. Gender and Development. 15(1):25-40.

Thapar-Björkert S and Morgan K J (2010) "But Sometimes I Think...They Put Themselves in the Situation": Exploring Blame and Responsibility in Interpersonal Violence. Violence Against Women 16(1):32-59.

UNDP (2013) Regional Human Development Report on Latin America: Citizen Security with a Human Face: Evidence and Proposals for Latin America. Available at: http://hdr.undp.org/en/content/citizen-security-human-face (accessed 11 June, 2018).

UNODC (United Nations Office on Drugs and Crime) (2013) Global Study on Homicide. Available at: www.unodc.org/gsh/ (accessed 11 June, 2018).

Walby S, Towers J and Francis B (2014) Mainstreaming domestic and genderbased violence into sociology and the criminology of violence. The Sociological Review 62(S2):187-214.

Wendt A E (1987) The Agent-Structure Problem in International Relations Theory. International Organization 41(3):335-370.

Westmarland N and Kelly L (2013) Why Extending Measurements of 'Success' in Domestic Violence Perpetrator Programmes Matters for Social Work. British Journal of Social Work 43(6):1092-1110.

Wilcox, P. (2006) Communities, Care and Domestic Violence Critical Social Policy 26(4): 722-747

Wilding P (2012) Negotiating Boundaries: Gender, Violence and Transformation in Brazil. Basingstoke: Palgrave Macmillan.

Williams P (2015) Everyday Peace? Politics, citizenship and Muslim lives in India. RGS-IBG Book Series.

Wilson K (2008) Reclaiming 'Agency', Reasserting Resistance. IDS Bulletin 39(6):83-91.

Young IM (2003) The Logic of Masculinist Protection: Reflections on the Current Security State. Signs: Journal of Women in Culture and Society 29(1):1-25.

Zulver J (2016) High Risk Feminism in El Salvador: Women's Mobilisation in Violent Times. Gender and Development 24(2):171-185. 
${ }^{1}$ In recent years, many Latin American countries have seen a violent backlash against so-called 'gender ideology' in which advances in women's rights are seen to threaten 'traditional' values (Careaga-Perz, 2016); eg: the 2018 election of Jair Bolsonaro in Brazil.

2 Bilge (2010) explores the highly polarized and judgmental interpretations of Muslim women's veiling practices as either evidence of anti-imperialism or subjugation.

${ }^{3}$ Kelly (1996) argues that feminists have shied away from exploring the violence of women, a reluctance that reflects the need to present the 'good woman', who can readily be understood as the deserving victim.

4 See Molyneux's (1998) distinction between strategic / practical gender interests.

${ }^{5}$ Globally there has been a proliferation of laws addressing VAWG resulting from decades of activism. Brazil's Maria de Penha law was introduced in 2006 and followed by a law on femicide (Friedman, 2009; FBSP, 2017). El Salvador's Special Integrated Law for Life Free from Violence for Women was enacted in 2012, with limited results (Hume and Kane, 2016).

${ }^{6}$ Despite the conservative tendencies of most Christian denominations within Brazil, there are a small number of progressive Churches and religious spaces can provide sanctuary for women away from men (Lorentzen and Mira, 2005; Garmany, 2010). Burdick highlights that there are few places that poor black women feel 'treated more equally than in a Pentecostal church' (Burdick, 1998:127 in Wilding, 2012:108).

7 The Spanish term 'negociar' was used. Community leaders argued they did not 'ask permission', but that they did have to 'negotiate' with gang members should they wish to organize an activity/receive a visitor.

8 These were the terms used by members of the 'Citizen Windows' in Greater San Salvador.

9 Women have historically used traditional gendered activities, such as mothering, kitting and sewing, as 'cover' against repressive groups. 